\title{
Sistem Pakar Diagnosa Penyakit Pohon Karet Dengan Metode Certainty Factor
}

\author{
Arifsyah $^{1^{*}}$, Anita Sindar ${ }^{2}$ \\ ${ }^{1,2}$ STMIK Pelita Nusantara \\ J1. Iskandar Muda No. 1 Medan 20154 \\ Corresponding e-mail : haito_ita@yahoo.com
}

\begin{abstract}
Abstrak - Rendahnya produksi karet rakyat disebabkan oleh berbagai faktor, salah satu penyebabnya adalah gangguan dari berbagai penyakit. Membangun sistem (komputer) yang cerdas untuk menganalisis masalah, mengamati sistem kerja seorang pakar atau pakar. Keahlian berasal dari pengembangan pengetahuan seseorang yang kompeten dan langsung memberikan instruksi untuk menyelesaikan suatu masalah. Certainty Factor adalah metode untuk membuktikan apakah suatu fakta tertentu atau tidak tertentu dalam bentuk metrik yang biasanya digunakan dalam sistem pakar. Metode ini sangat cocok untuk sistem pakar yang mendiagnosis sesuatu yang tidak pasti. Untuk menerapkan metode Certainty Factor ke sistem pakar, diperlukan data yang akan dimasukkan ke dalam sistem, diproses dan ditampilkan hasil diagnosis penyakit tanaman karet. Input: data jenis penyakit tanaman karet dan data gejala penyakit. Proses: melakukan analisis dan perhitungan untuk mendapatkan hasil diagnosis menggunakan metode Certainty Factor. Keluaran: informasi tentang diagnosis penyakit tanaman karet dan persentase tingkat kepercayaan dalam hasil diagnosis sesuai dengan aturan metode Faktor Kepastian.
\end{abstract}

Kata Kunci : Penyakit Karet, Diagnosis Gejala, Kombinasi Nilai, Certainty Factor

\section{Pendahuluan}

Karet termasuk komoditi unggulan tanaman perkebunan Indonesia. Tanaman karet (hevea brasiliensis) digolongkan sebagai tanaman perkebunan yang tumbuh diberbagai wilayah Indonesia, dan tanaman tahunan. Pengembangan perkebunan karet memberikan peranan penting bagi perekonomian nasional yaitu sebagai sumber devisa, bahan baku industri dan juga berperan dalam pelestarian lingkungan hidup. Beberapa daerah, karet diusahakan per orang menjadi tanaman utama sumber penghasilan rumah tangga. Penyakit tanaman dapat menimbulkan hambatan pada pertumbuhan dan kerusakan pada bagian tanaman, penurunan hasil secara langsung atau kematian tanaman secara tidak langsung. Permasalahan yang muncul dari petani yaitu kurangnya pengetahuan tentang gejala-gejala penyakit yang sering menyerang karet [1]. Diperlukan penanganan khusus yang cepat untuk menghindari kerugian produksi. Penyakit pada tanaman karet dengan kerugian besar umumnya disebabkan oleh cendawan. Penyakit yang disebabkan oleh bakteri dan virus kerugiannya tidak begitu besar. Penyakit tanaman karet menyerang dari area akar, batang, bidang sadap, hingga daun. Umumnya jenis penyakit karet adalah Jamur akar putih (JAP), Jamur Upas, Nekrosis Kulit, Penyakit Kering Alur Sadap (KAS), Penyakit Kering Alur Sadap (KAS), Penyakit Gugur Daun Colletotrichum [2]. Kecerdasan buatan (Artificial Intelligence) berhasil meniru cara kerja manusia yang berdasarkan penerapan ilmu pengetahuan. Kemampuan yang terlatih dipindahkan pada pengembangan aplikasi sistem kommputer berbasis pengetahuan. Proses pengimplementasian keahlian pakar pada komputer melibatkan akuisisi pengetahuan (dari pakar atau sumber lain), representasi pengetahuan (pada komputer), inferensi pengetahuan, pemindahan pengetahuan ke pengguna, inferensi (inferencing) [3]. Penyakit karet tersebar di perkebunan karet Indonesia dan menimbulkan kerusakan yang berbeda menurut lokasi kebun dan waktu yang berbeda. Penelitian tentang sistem pakar menggunakan metode Certainty Factor, (Novi Sri Wanti Ginting, 2018), mengasumsikan nilai keyakinan seorang pakar berdasarkan studi kasus hasil perhitungan Certainty Factor dengan nilai tertinggi yaitu 0,870418 yang artinya penyakit kacang kedelai mengalami penyakit penggulung daun [4].

\section{Tinjauan Pustaka}

Keahlian (kepakaran) bersumber dari knowledgebased expert system. Istilah ini muncul karena untuk memecahkan masalah, sistem pakar menggunakan pengetahuan seorang pakar yang dimasukkan ke dalam komputer [5]. Seorang yang bukan pakar menggunakan sistem pakar untuk meningkatkan kemampuan pemecahan masalah, sedangkan seorang pakar menggunakan sistem pakar untuk knowledge assistant. Sistem pakar dibangun seperti sistem komputer seakan-akan melakukan kepakaran (decision making) seorang pakar. Sistem pakar 
menerapkan secara maksimal keahlian seorang pakar untuk menyelesaikan permasalahan tanpa meragukan pengguna sistem. Pakar atau ahli (expert) didefenisikan kemampuan yang teruji memberikan penyelesaian masalah bersumber dari buku, jurnal, majalah, dan dokumentasi yang dipublikasikan lainnya,serta orang yang memiliki pengetahuan meskipun bukan ahli [6]. Expert system bersumber pada pengetahuan (knowledge-based system) atau dikategorikan menjadi sistem pakar berbasis pengetahuan (knowladge based expert system) [7]. Faktor kepastian diperkenalkan oleh Shortliffe Buchanan dalam pembuatan MYCIN Tim pengembang mencatat kebiasaan bahwa seorang dokter menganalisa informasi yang ada dengan ungkapan mungkin, kemungkinan besar, hampir pasti. Tim MYCIN menggunakan metode Certainty Factor (CF) guna menggambarkan tingkat keyakinan pakar terhadap permasalahan yang sedang dihadapi.Faktor kepastian dengan merupakan cara dari penggabungan kepercayaan dan ketidak kepercayaan dalam bilangan yang tunggal Certainty Factor (CF) menggunakan suatu nilai untuk mengasumsikan derajat keyakinan seorang pakar terhadap suatu data [8].

$$
\mathrm{CF}[\mathrm{H} . \mathrm{E}]=\mathrm{MB}[\mathrm{H}, \mathrm{E}]-\mathrm{MD}[\mathrm{H}, \mathrm{E}]
$$

Keterangan, $\mathrm{CF}=$ Certainty Factor hipotesa dalam hipotesis $\mathrm{H}$ yang dipengaruhi oleh fakta ; $\mathrm{MB}=$ meansure of believe, me rupakan nilai kenaikan dari kepercayaan hipotesis $\mathrm{H}$ dipengaruhi oleh fakta $\mathrm{E}$; $\mathrm{MD}=$ meansure of disbelieve, merupakan nilai kenaikan dari ketidakpercayaan hipotesis $\mathrm{H}$ dipengaruhi oleh fakta $\mathrm{E} ; \mathrm{H}=$ Hipotesis (dugaan); $\mathrm{E}$ = Evidence (Peristiwa/fakta).

Nilai CF digunakan rumus :

$$
\mathrm{CF}=\mathrm{MB}-\mathrm{MD}
$$

$\mathrm{CF}=$ Certainty Factor; $\mathrm{MB}=$ Nilai kepercayaan pakar(Meansure Believe); $\mathrm{MD}=$ Nilai ketidak percayaan pakar (Meansure Disbelieve).

\section{Metode Penelitian}

Kaidah produksi biasanya dituliskan dalam bentuk jika-maka (IF THEN). Kaidah ini dapat dikatakan sebagai hubungan impliksi dua bagian, yaitu bagian premise (jika) dan bagian konklusi (maka). Apabila bagian premise dipenuhi maka bagian konklusi juga akan bernilai benar. Sebuah kaidah terdiri dari klausa-klausa. Ada sebuah klausa premise dan klausa konklusi pada sebuah kaidah. Suatu kaidah juga dapat terdiri atas beberapa premise dan lebih darisatu konklusi. Antara premise dan konklusi dapat berhubungan dengan "OR" atau "AND" [9].

Untuk menerapkan metode Certainty Factor kedalam sistem pakar, diperlukan data yang nantinya akan input kedalam sistem, diolah dan menampilkan hasil diagnosa penyakit tanaman karet. Input: data jenis penyakit tanaman karet serta data gejala penyakit. Process : melakukan analisis dan perhitungan untuk mendapatkan hasil diagnosa dengan menggunakan metode Certainty Factor. Output : informasi hasil diagnosa penyakit tanaman karet dan persentase tingkat keyakinan terhadap hasil diagnosa tersebut sesuai dengan aturan-aturan metode Certainty Factor.

Tahapan penelitian yang dilakukan biasa selalu dimulai dengan identifikasi masalah agar memahami pokok permasalahan yang nantinya dapat memberikan solusi yang berguna. Data-data yang diperlukan untuk membangun sistem adalah seperti data penyakit tanaman karet, gejala-gejala penyakit tanaman karet, serta solusi penangannnya. Mengumpulkan data-data yang diperlukan dan menganalisa serta menyusun rancangan penelitian dan menerapkan hasil penelitian dan juga membuat laporan tentang hasil penelitian [10].

Analisis Metode Certainty Factor:

Sistem pakar diagnosa penyakit tanaman karet dengan metode Certainty Factor membutuhkan identifikasi terhadap gejala penyakit dan jenis penyakit tanaman karet. Keputusan yang dihasilkan dapat berupa probabilitas atau kemungkinan yang tergantung dari hasil suatu kejadian. Dalam pengolahan data dan pengambilan keputusan hasil diagnosa penyakit tanaman karet, metode Certainty Factor memiliki sebuah aturan:

JIKA E MAKA $\mathrm{H}: \mathrm{CF}(\mathrm{H}, \mathrm{e})=\mathrm{CF}(\mathrm{E}, \mathrm{e}) * \mathrm{CF}(\mathrm{H}, \mathrm{E}) \ldots$.

CFcombineCF[H,E $] 1,2=\mathrm{CF}[\mathrm{H}, \mathrm{E}] 1+\mathrm{CF}[\mathrm{H}, \mathrm{E}] 2 *[1-$

$\mathrm{CF}[\mathrm{H}, \mathrm{E}] 1] \ldots$

CFcombineCF[H,E]old, $3=\mathrm{CF}[\mathrm{H}, \mathrm{E}]$ old $+\mathrm{CF}[\mathrm{H}, \mathrm{E}] 3 *$ (1-CF[H,E] old]

Keterangan : $\mathrm{CF}(\mathrm{E}, \mathrm{e})$ : Certainty Factor evidence E yang dipengaruhi oleh evidence e $\mathrm{CF}(\mathrm{H}, \mathrm{E})$ : Certainty Factor hipotesis dengan asumsi evidence diketahui dengan pasti, yaitu ketika $\mathrm{CF}(\mathrm{E}, \mathrm{e})=1$. $\mathrm{CF}(\mathrm{H}, \mathrm{e})$ : Certainty Factor hipotesis yang dipengaruhi oleh evidence e.

\section{Hasil dan Pembahasan}

Data-data yang diperlukan untuk membangun sistem ini seperti data penyakit tanaman karet, gejalagejala penyakit tanaman karet, serta solusi penangannnya diperoleh dari tempat penelitian yaitu di PT. Perkebunan Nasional III, diperoleh data, Tabel 1. 
Tabel 1. Data Penyakit Tanaman Karet

\begin{tabular}{|c|c|c|c|}
\hline Kode & $\begin{array}{c}\text { Nama } \\
\text { Penyakit }\end{array}$ & Deskripsi & Pengobatan \\
\hline P1 & $\begin{array}{l}\text { Penyakit Akar } \\
\text { Putih }\end{array}$ & $\begin{array}{l}\text { Pada akar tanaman yang terserang } \\
\text { terlihat miselia jamur berbentuk } \\
\text { benang berwarna putih dan } \\
\text { menempel kuat dan sulit dilepas. } \\
\text { Akar tanaman yang terinfeksi akan } \\
\text { menjadi lunak, membusuk, dan } \\
\text { berwarna coklat. }\end{array}$ & $\begin{array}{l}\text { 1.Penyingiran dan pembakaran sisa sisa tunggul } \\
\text { tanaman lama di areal perkebunan, Menanam tanaman } \\
\text { penutup } \\
\text { terutama kacang kacangan. 2. Tanaman ini membantu } \\
\text { mempercepat penguraian akar akar tanaman yang } \\
\text { tersisa. 3. Menanam bibit karet yang bebas bibit } \\
\text { penyakit akar putih. } 4 \text {. Membenamkan belerang untuk } \\
\text { melindungi tanaman baru jika ditanam pada lahan } \\
\text { bekas perkebunan karet. 5. Jangan menanam ubi jalar } \\
\text { dan ubi kayu di sela tanaman karet karena tanaman ini } \\
\text { sebagai inang penyakit tanaman putih. } 6 \text {. Membongkar } \\
\text { tanaman sakit yang sudah parah. Dan di bekas galian } \\
\text { harus di bubuhi belerang sebanyak } 200 \text { gram. }\end{array}$ \\
\hline $\mathrm{P} 2$ & $\begin{array}{l}\text { Penyakit Akar } \\
\text { Merah }\end{array}$ & $\begin{array}{l}\text { Penyakit yang disebabkan oleh } \\
\text { ganoderma pseudoperrum. Bentuk } \\
\text { badan buah jamur berbentuk } \\
\text { topidan tersusun pada pangkal } \\
\text { batang tanaman. Permukaan badan } \\
\text { atas berwarna merah coklat, dan } \\
\text { permukaan bawahnya berwarna } \\
\text { putih kelabupenuh lubang kecil } \\
\text { tempat spora. }\end{array}$ & $\begin{array}{l}\text { 1. Pemeriksaan dilakukan selama } 6 \text { atau } 12 \text { bulan sekali } \\
\text { terutama untuk tanaman yang berumur di bawah } 5 \\
\text { tahun. 2. Pengendalian harus segera dilakukan bila } \\
\text { terjadi pucat atau kuning dan akiar terdapat micellia } \\
\text { merah. 3. Tanaman yang sudah di kendalikan } \\
\text { penyakitnya haruslah di perinksa lagi untuk } \\
\text { memastikan penyakit benar benar terkendalikan. }\end{array}$ \\
\hline P3 & Jamur Upas & $\begin{array}{l}\text { Penyakit yang disebabkan oleh } \\
\text { upasia salmonicolor. Penyakit } \\
\text { jamur upas menyerang } \\
\text { percabangan atau batang tanaman } \\
\text { sehingga mengakibatkancabang } \\
\text { dan tajuk mudah patah atau mati. } \\
\text { Seranganya sering di jumpai pada } \\
\text { tanaman muda antara 3-7 tahun. }\end{array}$ & $\begin{array}{l}\text { 1. Penanaman tanaman yang tahan terhadap penyakit } \\
\text { jamur upas, seperti; GT 1, PR 255, PR 300, PR 107. } 2 \text {. } \\
\text { Penanaman sesuai anjuran dan sesuai keadaan di daerah } \\
\text { tersebut. 3. Pengendalian dilakukan secepat mungkin } \\
\text { saat tingkat sarang laba laba. 4. Tanaman yang sudah } \\
\text { mati haru segera di musnahkan dan tunggul di taburi } \\
\text { pungisida. 5. Jika percabangan sudah terkena, maka } \\
\text { kulit harus di kupas dan dilumuri pungisida. }\end{array}$ \\
\hline P4 & $\begin{array}{l}\text { Kanker } \\
\text { Bercak } \\
\text { Penyebab } \\
\text { Penyakit Ini } \\
\text { Ialah Jamur }\end{array}$ & $\begin{array}{l}\text { Phytopthora Palmivora Kerusakan } \\
\text { karna penyakit kanker bercak ialah } \\
\text { kerusakan pada kulit luar bidang } \\
\text { sadap atau kulit percabangan } \\
\text { sehingga tanaman akan tumbuh } \\
\text { tidak normal dan akhirnya mati }\end{array}$ & $\begin{array}{l}\text { Penanaman tahan penyakit sperti GT } 1 \text {. 2. Jarak tanam } \\
\text { datur sesuai daerah dan anjuran. } 3 \text {. Sanistasi yang baik } \\
\text { 4. Kulit yang membusuk di potong sampai ke bagian } \\
\text { yang sehat. }\end{array}$ \\
\hline P5 & Nekrosis Kulit & $\begin{array}{l}\text { Nekrosis kulit kemungkinan } \\
\text { disebabkan oleh jamur Fusarium } \\
\text { sp. Namun Botryodiplodia } \\
\text { theobromae juga ditemukan pada } \\
\text { kulit yang sakit dengan } \\
\text { menimbulkan gejala yang sama. }\end{array}$ & $\begin{array}{l}\text { 1. Tidak menanam klon yang peka penyakit nekrosis } \\
\text { seperti GYT 557, GT 1, dan AVROS } 2037 \text { pada daerah } \\
\text { yang rawan penyakit ini. } 2 \text {. Pemeliharaan tanaman } \\
\text { dengan pemupukan dan penyiangan sesuai dengan } \\
\text { anjuran. 3. Pengobatan tanaman dengan pengolesan } \\
\text { fungisisda difolatan, indafol, atau calixin dengan kuas } \\
\text { pada kulit yang sakit setelah kulit yang busuk dikupas } \\
\text { terlebih dahulu. } 4 \text {. Bagian kulit yang busuk dikerok } \\
\text { kenmudian ditutup dengan TB } 192 \text { untuk mencegah } \\
\text { masuknya kumbang penggerek batang/cabang. } 5 . \\
\text { Tanaman yang sehat yang berada di sekitar tanaman } \\
\text { yang sakit disemprot batangya dengan menggunakan } \\
\text { indafol } 476 \text { seminggu sekali untuk mencegah } \\
\text { penyebaran penyakit yang lebih luas. } 6 \text {. Tanaman yang } \\
\text { mengalami serangan berat diistirahatkan, tidak disadap } \\
\text { sampai tanaman kembali pulih. }\end{array}$ \\
\hline
\end{tabular}




\begin{tabular}{|c|c|c|c|}
\hline P6 & & $\begin{array}{l}\text { Penyebab penyakit ini adalah } \\
\text { cendawan Ceratocystis } \\
\text { jimbriata dengan benang-benang } \\
\text { hifa yang membentuk lapisan } \\
\text { berwarna kelabu di bagian yang } \\
\text { terserang }\end{array}$ & $\begin{array}{l}\text { 1. Jarak tanam jangan terlalu rapat dan tanaman } \\
\text { penutup tanah rutin dipangkas agar kebun tidak lembab. } \\
\text { 2. Kegiatan penyadapan jangan terlalu sering dan jika } \\
\text { perlu saat serangan menghebat kegiatan penyadapan } \\
\text { dihentikan. 3. Sebelum penyadapan, pisau yang akan } \\
\text { digunakan dicelupkan ke larutan Difolatan } 4 \text { F } 1 \% \text { atau } \\
\text { Difolatan } 80 \mathrm{WP} 1 \%\end{array}$ \\
\hline P7 & $\begin{array}{l}\text { Penyakit } \\
\text { Kering Alur } \\
\text { Sadap (Kas) }\end{array}$ & $\begin{array}{l}\text { Cendawan penyebab penyakit } \\
\text { kanker garis sama dengan biang } \\
\text { keladi kanker bercak, yakni } \\
\text { Phytophthora } \\
\text { palmivora. Cendawan ini } \\
\text { mengakibatkan kerusakan di bekas } \\
\text { bidang sadap lama, sehingga } \\
\text { penyadapan berikutnya sulit } \\
\text { dilakukan. }\end{array}$ & $\begin{array}{l}\text { 1. Penyadapan jangan terlalu dalam dan tidak terlalu } \\
\text { dekat dengan tanah. } 2 \text {. Sebelum digunakan pisau sadap } \\
\text { diolesi fungisida Difolatan } 4 \text { F } 1 \% \text { atau Difolatan } 80 \\
\text { WPl \%. 3. Mengoleskan fungisida Difolatan } 4 \text { F } 2 \% \text {, } \\
\text { Difolatan } 80 \text { WP 2\%, Demosan 0,5\%, atau Actidione } \\
0,5 \% \text { di jalur selebar 5-10 cm di atas dan di bawah } \\
\text { alur sadap menggunakan kuas segera setelah dilakukan } \\
\text { penyadapan atau paling baik setelah pemungutan lateks } \\
\text { yang belum membeku. Setelah sembuh, bidang sadap } \\
\text { ditutup dengan Secony CP 2295 A. }\end{array}$ \\
\hline
\end{tabular}

Gejala-gejala penyakit tanaman karet yang diperoleh berdasarkan hasil riset, 1) G1 Daun terlihat pucat dan suram 2) G2 Tepi daun terlipat kedalam 3) G3 Ujung ranting mati 4) G4 Daun gugur 5) G5 Adanya benangbenang jamur berwarna putih di akar 6) G6 Akar tanaman membusuk 7) G7 Pada pangkal akar adanya cendawan seperti topi, berwarna putih kekuningkuningan 8) G8 Adanya benang- benang jamur berwarna merah pada akar 9) G9 Apabila akar ditekan akan mengeluarkan cairan 10) G10 Adanya cendawan berwarna merah pada akar 11) G11 Adanya benang-benang berwarna putih pada permukaan batang 12) G12 Mengeluarkan cairan dipermukaan batang 13) G13 Permukaan kulit batang membusuk 14) G14 Bagian kayu menjadi rusak dan menghitam 15) G15 Berbau busuk 16) G16 Permukaan kulit batang pecah- pecah 17) G17 Adanya bercak coklat kehitaman pada batang 18) G18 Adanya bercak basah 19) G19 Adanya bercak berwarna putih 20) G20 Apabila dikorek, kulit akan tampak bintik- bintik berwarna coklat 21) G21 Bidang sadapan mengalami kerusakan 22) G22 Tidak mengalirnya lateks 23) G23 Daerah sadapan menjadi kering 24) G24 terdapat pembengkakan / tonjolan.

Sebuah kaidah terdiri dari klausaklausa. Ada sebuah klausa premise dan klausa konklusi pada sebuah kaidah. Suatu kaidah juga dapat terdiri atas beberapa premise dan lebih darisatu konklusi. Antara premise dan konklusi dapat berhubungan dengan "OR" atau "AND". Basis aturan disajikan dalam aturan-aturan yang berbentuk pasangan keadaan aksi (conditionaction) "JIKA (IF) keadaan terpenuhi atau terjadi MAKA (THEN)" :

Rule 1: IF Daun terlihat pucat dan suram is True AND Tepi daun terlipat kedalam is True AND Ujung ranting mati is True AND Daun gugur is True
AND Adanya benang- benang jamur berwarna putih di akar is True

AND Akar tanaman membusuk is True

AND Pada pangkal akar adanya cendawan seperti topi, berwarna putih kekuningkuningan is True

THEN Penyakit Akar Putih

Rule 2: IF Daun terlihat pucat dan suram is True AND Daun gugur is True

AND Akar tanaman membusuk is True AND Adanya benang- benang jamur berwarna merah pada akar is True

AND Apabila akar ditekan akan mengeluarkan cairan is True

AND Adanya cendawan berwarna merah pada akar is True

THEN Penyakit Akar Merah

Rule 3: IF Daun gugur is True

AND Adanya benang-benang berwarna putih pada permukaan batang is True

AND Mengeluarkan cairan dipermukaan batang is True

AND Permukaan kulit batang membusuk is True

AND Bagian kayu menjadi rusak dan menghitam is True

THEN Jamur Upas

Rule 4: IF Adanya benang-benang berwarna putih pada permukaan batang is True

batang is True

AND Mengeluarkan cairan dipermukaan

AND Berbau busuk is True

AND Permukaan kulit batang pecah- pecah

is True

THEN Kanker Bercak

Rule 5: IF Permukaan kulit batang membusuk is True AND Permukaan kulit batang pecah- pecah is True

AND Adanya bercak coklat kehitaman pada batang is True

AND Adanya bercak basah is True 
THEN Nekrosis Kulit

Rule 6: IF Permukaan kulit batang membusuk is True AND Adanya bercak berwarna putih is True AND Apabila dikorek, kulit akan tampak bintik- bintik berwarna coklat is True

AND Bidang sadapan mengalami kerusakan

is True

THEN Penyakit Bidang Sadapan Mouldy rot

Rule 7: IF Permukaan kulit batang pecah- pecah is True

AND Tidak mengalirnya lateks is True

AND Daerah sadapan menjadi kering is

True

AND Adanya terdapat pembekakan / tonjolan is True

THEN Penyakit Kering Alur Sadap

Tingkat keyakinan jawaban pengguna, terhadap hasil yang didapatkan maka digunakanlah Certainty Factor. Dalam sistem ini untuk mendapatkan faktor kepastian, setiap jawaban dari pengguna akan memiliki bobotnya masing-masing, Tabel 2.

Tabel 2. Tingkat Keyakinan Jawaban Pengguna

\begin{tabular}{|l|c|}
\hline \multicolumn{1}{|c|}{ Certainty Term } & Certainty Faktor \\
\hline Tidak & 0 \\
\hline Tidak Tahu & 0.2 \\
\hline Sedikit Yakin & 0.4 \\
\hline Cukup Yakin & 0.6 \\
\hline Yakin & 0.8 \\
\hline Sangat Yakin & 1.0 \\
\hline
\end{tabular}

Sebuah kasus penyakit tanaman karet, dimana gejala penyakit dan jawaban yang diberikan pengguna $\mathrm{CF}[\mathrm{H}, \mathrm{E}] 1$ Daun terlihat pucat dan suram $\square$ Sangat Yakin ; $\mathrm{CF}[\mathrm{H}, \mathrm{E}] 2$ Tepi daun terlipat kedalam $\square$ Sangat Yakin ; CF[H,E]3 Ujung ranting mati $\square$ Cukup Yakin; CF[H,E]4 Daun gugur $\square$ Yakin ; $\mathrm{CF}[\mathrm{H}, \mathrm{E}] 5$ Adanya benang- benang jamur berwarna putih di akar Sedikit Yakin ; CF[H,E]6 Akar tanaman membusuk $\square$ Cukup Yakin; CF[H,E]7 Pada pangkal akar adanya cendawan seperti topi, berwarna putih kekuning-kuningan $\square$ Sangat Yakin Maka nilai $\mathrm{CF}(\mathrm{H}, \mathrm{E})$ adalah: $\mathrm{CF}[\mathrm{H}, \mathrm{E}] 1=\mathrm{CF}[\mathrm{H}] 1{ }^{*} \mathrm{CF}[\mathrm{E}] 1=0.4$; $\mathrm{CF}[\mathrm{H}, \mathrm{E}] 2=\mathrm{CF}[\mathrm{H}] 2 * \mathrm{CF}[\mathrm{E}] 2=0.8 * 1=0.8$ $\mathrm{CF}[\mathrm{H}, \mathrm{E}] 3=\mathrm{CF}[\mathrm{H}] 3 * \mathrm{CF}[\mathrm{E}] 3=0.8 * 0.6=0.48$ $\mathrm{CF}[\mathrm{H}, \mathrm{E}] 4=\mathrm{CF}[\mathrm{H}] 4 * \mathrm{CF}[\mathrm{E}] 4=0.3 * 0.8=0.24$ $\mathrm{CF}[\mathrm{H}, \mathrm{E}] 5=\mathrm{CF}[\mathrm{H}] 5 * \mathrm{CF}[\mathrm{E}] 5=0.9 * 0.4=0.36$ $\mathrm{CF}[\mathrm{H}, \mathrm{E}] 6=\mathrm{CF}[\mathrm{H}] 6 * \mathrm{CF}[\mathrm{E}] 6=0.7 * 0.6=0.42$ $\mathrm{CF}[\mathrm{H}, \mathrm{E}] 7=\mathrm{CF}[\mathrm{H}] 7 * \mathrm{CF}[\mathrm{E}] 7=0.9 * 1=0.9$

Kombinasi Nilai CF[H,E]berdasarkan perhitungan di atas untuk masing-masing gejala penyakit CFcombine $\mathrm{CF}[\mathrm{H}, \mathrm{E}] 1,2=\mathrm{CF}[\mathrm{H}, \mathrm{E}] 1+\mathrm{CF}[\mathrm{H}, \mathrm{E}] 2 *(1$ $-\mathrm{CF}[\mathrm{H}, \mathrm{E}] 1)=0.4+0.8 *(1-0.4)=0.4+0.32=0.72$ $\square$ old 1 ; CFcombine CF[H,E]old1,3 = CF[H,E]old $1+$
$\mathrm{CF}[\mathrm{H}, \mathrm{E}] 3 *(1-\mathrm{CF}[\mathrm{H}, \mathrm{E}] \mathrm{old} 1)=0.72+0.48 *(1-$ $0.72)=0.8544=$ old $2 ;$ CFcombine CF $[\mathrm{H}, \mathrm{E}] \mathrm{old} 2,4=$ $\mathrm{CF}[\mathrm{H}, \mathrm{E}]$ old $2+\mathrm{CF}[\mathrm{H}, \mathrm{E}] 4 *(1-\mathrm{CF}[\mathrm{H}, \mathrm{E}] \mathrm{old} 2)=0$. $8544+0.24 *(1-0.8544)=0.889344=$ old 3 ; CFcombine $\mathrm{CF}[\mathrm{H}, \mathrm{E}] \mathrm{old} 3,5=\mathrm{CF}[\mathrm{H}, \mathrm{E}] \mathrm{old} 3+$ $\mathrm{CF}[\mathrm{H}, \mathrm{E}] 5 *(1-\mathrm{CF}[\mathrm{H}, \mathrm{E}] \mathrm{old} 3)=0.889344+0.36 *(1$ - 0.889344) $=0.92918016=$ old $4 ;$ CFcombine $\mathrm{CF}[\mathrm{H}, \mathrm{E}]$ old4, $6=\mathrm{CF}[\mathrm{H}, \mathrm{E}] \mathrm{old} 4+\mathrm{CF}[\mathrm{H}, \mathrm{E}] 6 *(1-$ $\mathrm{CF}[\mathrm{H}, \mathrm{E}] \mathrm{old} 4) ; \quad=0.92918016+0.42 *(1-$ $0.92918016)=0.9589259328=$ old $5 ;$ CFcombine $\mathrm{CF}[\mathrm{H}, \mathrm{E}]$ old $5,7=\mathrm{CF}[\mathrm{H}, \mathrm{E}] \mathrm{old} 5+\mathrm{CF}[\mathrm{H}, \mathrm{E}] 7 *(1-$ $\mathrm{CF}[\mathrm{H}, \mathrm{E}]$ old5 $) ; \quad=0.9589259328+0.9 *(1 \quad-$ $0.9589259328)=0.99589259328$. Maka nilai persentase tingkat kepercayaan pengguna terhadap sistem pakar yang mendiagnosa penyakit tanaman karet berdasarkan kasus di atas adalah Persentase = CFPenyakit $* 100=0.99589259328 * 100=99.58 \%$. Implementasi sistem merupakan tahapan untuk menjalankan sistem dalam bentuk hasil tangkapan layar dari sistem yang sedang dijalankan dan setiap gambar dilengkapi dengan penjelasan. Halaman Utama Pengunjung, halaman khusus untuk pengunjung aplikasi sistem pakar. Halaman ini dapat diakses oleh pengunjung ketika sistem dijalankan, Gambar 1. Pada halaman ini, pengujung dapat melakukan diagnosa penyakit pada pohon karet. Langkah yang harus dilakukan adalah dengan mengisi data pengunjung lalu klik tombol Mulai Deteksi, Gambar 2.

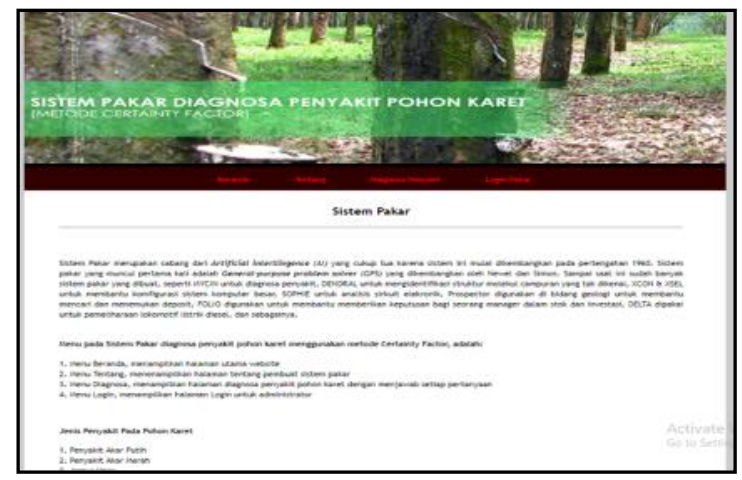

Gambar 1. Halaman Menu Utama

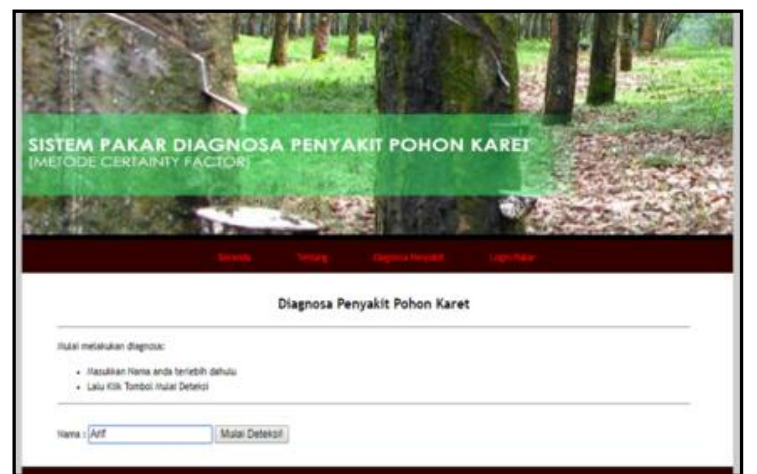

Gambar 2. Halaman Pengunjung 
Setelah pengujung memasukkan nama pada halaman sebelumnya, maka sistem akan menampilkan halaman diagnosa. Pengujung akan diberikan pertanyaan berupa gejala-gejala penyakit pada pohon karet, dan pengunjung akan menjawab pertanyaan hingga selesai, Gambar 3. Halaman Hasil Diagnosa menampilkan hasil diagnosa, Gambar 4.

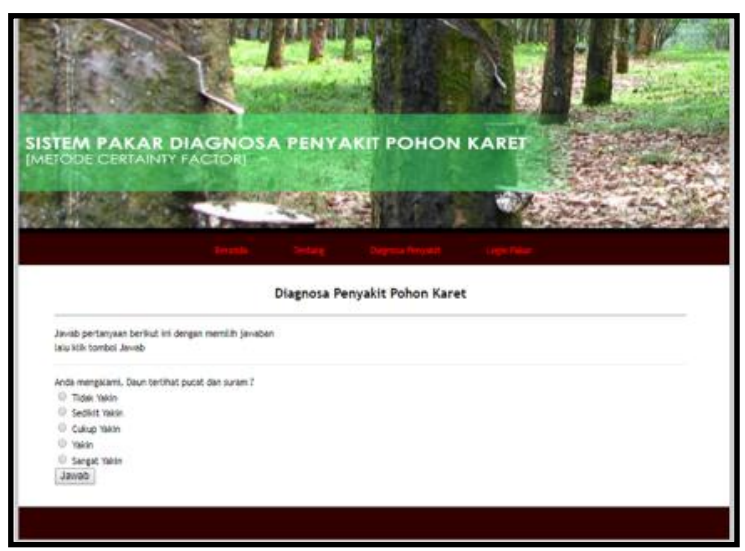

Gambar 3. Halaman Diagnosa

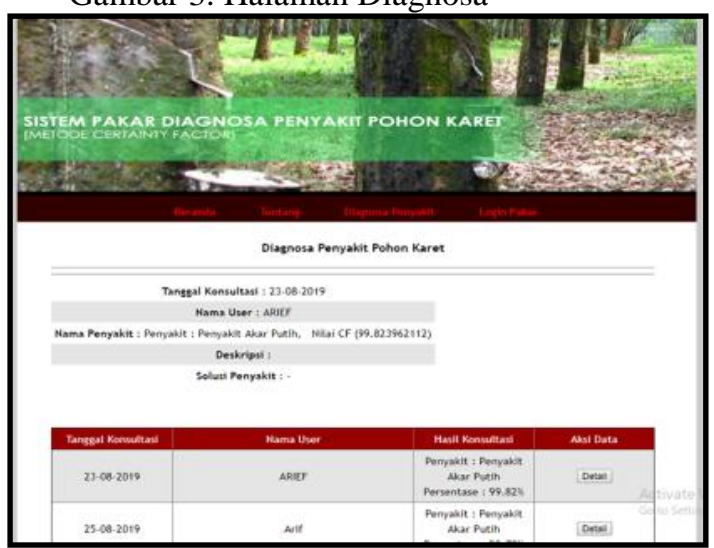

Gambar 4. Halaman Hasil Diagnosa

\section{Kesimpulan}

Kesimpulan dari penelitian :

1. Rancangan tampilan form hasil diagnosa digunakan melihat hasil mendiagnosa penyakit tanaman karet berdasarkan jawaban-jawaban yang telah diberikan pengguna umum sebelumnya (bentuk kepakaran).

2. Apabila bagian premise dipenuhi maka bagian konklusi juga akan bernilai benar, suatu kaidah juga dapat terdiri atas beberapa premise dan lebih dari satu konklusi. Antara premise dan konklusi dapat berhubungan dengan "OR" atau "AND".

3. Sistem dapat menampilkan informasi data penyakit, gejala, solusi penanganan penyakit dan juga menampilkan hasil diagnosa penyakit pada pohon karet.

\section{Daftar Pustaka}

[1] Aryu Hanifah Aji, M. Tanzil Furqon, Agus Wahyu Widodo, Sistem Pakar Diagnosa Penyakit Ibu Hamil Menggunakan Metode Certainty Factor (CF), Jurnal Pengembangan Teknologi Informasi dan Ilmu Komputer, Vol. 2, No. 5, , hlm. 2127-2134, Mei 2018.

[2] D. Suryadi, R. Meilianda, A. Suryono, and M. Munadi, "Sistem Pakar untuk Mengidentifikasi Kerusakan Mesin Industri Menggunakan Metode Certainty Factor," ROTASI, vol. 20, no. 1, pp. 56-62, Jan. 2018.

[3] Khairina Eka Setyaputri, Abdul Fadlil, dan Sunardi, Analisis Metode Certainty Factor pada Sistem Pakar Diagnosa Penyakit THT, Jurnal Teknik Elektro Vol. 10 No. 1, hal. 30-36, Januari - Juni 2018

[4] Novi Sri Wanti Ginting, Anita Sindar RMS, Sistem Pakar Diagnosa Penyakit Kacang Kedelai Menggunakan Metode Certainty Factor, UPI YPTK Jurnal KomTekInfo Vol. 5, No. 1, , Hal.36-41. Desember 2018.

[5] Yuliyana, Anita Sindar Ros Maryana Sinaga, Sistem Pakar Diagnosa Penyakit Gigi Menggunakan Metode Naive Bayes, Fountain of Informatics Journal Volume 4, No. 1, hal. 1923.Mei 2019.

[6] Rudi Hariyanto, Khalimatus Sa'diyah, "Sistem Pakar Diagnosis Penyakit dan Hama Pada Tanaman Tebu Menggunakan Metode Certainty Factor", Journal of Information Technology and Computer Science (JOINTECS), Vol. 3, No.1, hal 179-181, Januari 2018

[7] Stephanie Halim, Seng Hansun, Penerapan Metode Certainty Factor dalam Sistem Pakar Pendeteksi Resiko Osteoporosis dan Osteoarthritis, ULTIMA Computing, Vol. VII, No. 2 | hal 59-69, Desember 2015.

[8] Roindah Simalango, Anita Sindar Sinaga, Bayes Diagnosa Penyakit Ikan Hias Air Tawar Dengan Teorema Bayes, SinKron, Volume 3 Nomor 1, hal: 43-50, Oktober 2018.

[9] Siti Mujilahwati, Diagnosa Penyakit Tanaman Hias Menggunakan Metode Certainty Factor Berbasis Web, JURNAL Tekknika V ol 6 N0 2 hal. 585-591, September 2014.

[10] Sri Rahayu, Anita Sindar RM Sinaga, Penerapan Metode Naive Bayes Dalam Pemilihan Kualitas Jenis Rumput Taman CV. Rumput Kita Landscape, Jurnal Teknologi Informasi \& Komunikasi Digital Zone, Volume 9, Nomor 2, hal: 162-171 November 2018. 